\title{
DEVELOPING THE NEW MULTI RUST RESISTANT BREAD WHEAT CULTIVAR "MAAROOF" FOR THE IRRIGATED AND RAIN-FED ZONES OF IRAQ
}

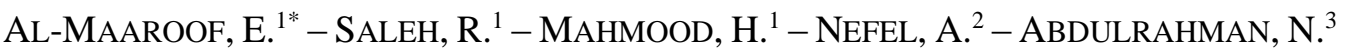 \\ ${ }^{1}$ College of Agricultural Sciences Engineering, University of Sulaimani, Iraq \\ ${ }^{2}$ Ministry of Science and Technology, Iraq \\ ${ }^{3}$ Ministry of Agriculture and Water Resources, IKR, Iraq \\ ${ }^{*}$ Corresponding author \\ e-mail:ealmaaroof@yahoo.com; emad.ghalib@univsul.edu.iq
}

(Received $10^{\text {th }}$ Oct 2019; accepted $30^{\text {th }}$ Jan 2020)

\begin{abstract}
Following the designation of R-30 as a source of resistance to the three rusts; it was successfully introduced in a breeding program with Tamuz 2 using the pedigree method in 1997. The progenies of three successive generations (F3-F5) were screened for resistance to the three rusts under artificial inoculation conditions at the adult plant stage in Twaitha. Out of 135 hybrid lines, 12 promising lines were selected. The selected lines were introduced in a comprehensive evaluation test for yield potential and response to rusts and bunt diseases in different locations. As a result, the promising line "63" was selected due to its high grain yield in the presence and absence of rusts and bunt diseases. Yield potential of the genotype is 10-19\% higher than that of the local commercial cultivars Araz and Tamuz 2. Maaroof was registered and released as a new cultivar with high yield potential and multi resistance to rusts and bunt diseases by the National Committee of Registration and Release of Agricultural Cultivars/Iraqi ministry of agriculture. There was a great emphasis on multiplication and delivery of the seeds to farmers. Yield potential of Maaroof on farm-scale was 3750 and $4750 \mathrm{~kg} / \mathrm{ha}$ under rain-fed and irrigated conditions respectively.
\end{abstract}

Keywords: Triticum aestivum, host resistance, wheat rusts, new genotypes, Iraq

\section{Introduction}

Wheat (Triticum aestivum L.) is one of the most essential and strategic cereal crops for the majority of the world's population. It is the most critical staple food for about two billion people ( $36 \%$ of the world population). Worldwide, wheat provides nearly $55 \%$ of the carbohydrates and 20\% of the food calories consumed globally (FAOSTAT, 2018). Wheat production area's in Iraq is divided into rain-fed and irrigated zones. Rain-fed areas are mainly in the north including Kurdistan region. An estimated 3.0 million tons of wheat were harvested in 2018, with a $14 \%$ reduction from 2017 production and $20 \%$ from the past five-year average, largely due to unfavorable environmental conditions. Nearly the same amount of wheat had been purchased by mid-August 2018 (FAO, 2018). In 2015, USDA projected that Iraq would continue to experience a long-term shortfall in wheat production and that it would need to import 3.8 million tons in 2015-16, followed by larger quantities each year after. By 2024-25, it projected that Iraq would require 4.9 million tons of wheat imports annually (USDA, 2015).

Biotic and abiotic stress particularly drought and salinity, are the leading causes of losses in wheat production. Many diseases can attack wheat, mainly caused by fungi, bacteria, and viruses. Yellow, brown and black stem rust diseases incited by the fungi Puccinia striiformis $\mathrm{f}$. $\mathrm{sp}$ tritici, $P$. triticina and $P$. graminis $\mathrm{f}$ sp. tritici respectively are the most critical grain yield-limiting factor of wheat in Iraq followed by common bunt 
disease; Tilletia tritici and T. laevis (Al-Maaroof et al., 2001, 2005, 2012). Yield losses due to the three rusts on wheat cultivars vary from 10 to $70 \%$ depending on the levels of resistance, stage of the crop at disease onset, pathogen races and, the environmental conditions (Al-Maaroof et al., 2001; Al-Maaroof and Nori, 2018).

Breeding for disease resistance is the most sustainable strategy to reduce yield losses, and also it is an environmentally safe approach to control the diseases (Line and Chen, 1995; Singh and Trethowan, 2007). Great importance is given to improve disease resistance in wheat using different breeding programs in Iraq (Ibrahim et al., 1993a,b). Several resistant and high yielding wheat cultivars were released in the nineteens (NCFRRAV, 2014). Successive release of the resistant cultivars participated in reducing grain yield losses caused by rust (Al-Maaroof et al., 2001, 2005, 2012). With the introduction of the resistant varieties new virulence's and races of rust pathogens also develop due to mutation or genetic recombination's that have contributed in switching resistance of these varieties (Al-Maaroof et al., 2003, 2005, 2010, 2012). Therefore, breeding for resistance to rust diseases and developing new resistant cultivars having higher yield potential became the main target in all wheat breeding programs and considered as the most economical and effective way to eliminate the use of fungicides and reducing crop losses caused by the disease (Singh et al., 2004).

The present study represents a long term breeding program for developing a new multiresistant bread wheat cultivar "Maaroof" with different levels of resistance to brown, yellow, stem rust and common but diseases.

\section{Material and Methods}

Following designation of R-30 as a source of multiple resistance to the three rusts among hundreds of genotypes that was previously tested to rust diseases for five consecutive season under artificial inoculation conditions with the prevalent dominant races of the pathogens in different environmental conditions in Iraq (Al-Maaroof et al., 2002); it has successfully introduced in a breeding program with the promising local cultivar Tamuz 2 using the pedigree method in 1997. The progenies of three successive generations (F3-F5) were screened to the three rusts under artificial inoculation conditions at the adult plant stage in Twaitha research experimental station. The test variants were planted in a single 2-meter long, $30 \mathrm{~cm}$ apart. The highly susceptible cultivars Morocco and SaberBeg were used as spreaders. One hundred thirty-five hybrid lines were evaluated based on their desired agricultural characteristics, drought tolerance and resistance to rust and common bunt diseases in observation and preliminary comparative experiments with the parents under both irrigated and rain-fed conditions (Pessarakli, 2011). The best 12 selected genotypes were introduced in small scale yield trial conducted at Latifia and Bakrajo experimental stations in 6 rows plot of $4.0 \mathrm{~m}$ length spaced at $30 \mathrm{~cm}$ along with the local checks in RCBD with three replicates. Comprehensive evaluation test for grain yield potential, grain quality and response to the three rusts and bunt diseases were promoted in multi locations and agro-system in Large scale yield trial tests using RCBD with three replications in 16 rowed plots of $6.0 \mathrm{~m}$ length spaced at $30 \mathrm{~cm}$. The recommended agricultural practices were adopted to raise a satisfactory crop as per ministry of agriculture (MOA) standards.

Artificial inoculations with a mixture of field collection of the three rust prevalent virulence's were carried out during March in each location using aqueous uredospore suspension to which two drops of Tween-20 were added to break the surface tension. 
Seeds of each genotype were artificially inoculated with a bulk population of $T$. tritici, $T$. laevis and T. intermedia teliospores collected from different locations in the previous season at a rate of $0.5 \mathrm{~g} / 100 \mathrm{~g}$ seeds. Inoculated seeds were mechanically mixed for 15 minutes by shaker at $80 \mathrm{rpm} /$ minute (Gotes, 1996). Each genotype was planted by hand at a depth of $5 \mathrm{~cm}$ in two $1.5 \mathrm{~m}$ rows ( $5 \mathrm{~g}$ seed/line) spaced $30 \mathrm{~cm}$ between lines and $60 \mathrm{~cm}$ between treatments at Twaitha, Baghdad (Irrigated) and Talefar, Nineveh (Rain-fed).

Disease scoring for the three rusts was recorded as infection type on each genotype (Stakman et al., 1962; Lewllen et al., 1967) and disease severity as percent infection on the plants according to the modified Cobb's Scale (Peterson et al., 1948). Coefficient of Infection (CI) was calculated by multiplying the response value with the intensity of infection in percent (Roelfs et al., 1992). Infection percent of each genotype to common bunt disease was calculated at dough stage by counting the number of healthy and infected spike per each meter according to Dodov and Todorova (1974) modified method.

During the coordinated evaluation, data on agronomic traits including plant height, flag leaf area, stem width, spike length and awn length were recorded from ten random plants in each experimental unit; yield component traits including number of spike per square meter, spike weight, thousand grain weight, number of grain per each spike, grain weight per each spike were calculated from 50 randomly selected spikes from each plot at dough stage; grain yield was calculated by random harvesting of plant spikes in one meter square from the center of each plot at dough stage when the grain moisture was 14\% (Bell and Fischer, 1994); disease resistance, quality attributes, and agronomical manipulations were also recorded (AACC, 2000; Salman and Mahdi, 2005). All the data were statistically analyzed at $\mathrm{p}=0.05$ significant levels using the method of analyses of variance (ANOVA). Least significant differences at $5 \%$ level were used to compare the mean of traits.

The high yielding resistant promising genotypes were sent for registration and release by the ministry of agriculture. Great emphasis was done on multiplication of high-grade seed of the new cultivar "Maaroof" then delivering them to the farmers.

\section{Results and Discussion}

Results of screening (R-30/Tamuz2) hybrid variants to the three kind of rusts and common bunt diseases under artificial inoculation conditions at the adult plant stage and some other agronomic traits are represented in Table 1. In general, out of 135 tested variants; 18 resistant and 43 moderately resistant were identified to brown, yellow and stem rust diseases either alone or in combinations, while 38 genotypes out yielded their parents and 31 variants characterized with earliness on their parents. Eleven variants continued in their resistance to brown rust through the study period, while 8 and 5 variants explored resistant reaction to yellow and stem rust diseases, respectively. Moderately resistance reaction was diagnosed in 26, 19 and, 5 variants to brown, yellow and stem rust diseases, respectively. Common bunt disease resistance was identified in 5 resistant and 18 moderately resistant variants, respectively. Thirty-three and 65 variants were resistant and moderately resistant to lodging, while six variants only showed drought tolerance. Selection of the variants for further studies were carried out based on their resistance to the target disease alone or in combination accompanied with yield and yield components with other agronomic traits, where number of selected resistant and moderately resistant variants reached to $9,12,8,14,17$ and 5 in brown rust, yellow rust, 
stem rust, common bunt, lodging, and drought tolerance tests. Among the selected variants, the best 12 genotypes were introduced in small yield trails.

Table 1. Host reaction of (R-30/Tamuz 2) hybrid variants to Yellow, brown stem rusts and common bunt diseases and some other related agricultural traits during 2001 to 2003 at Twaitha and Telafar experimental stations, Iraq

\begin{tabular}{c|c|c|c|c|c|c|c}
\hline \multirow{2}{*}{ Target Traits } & \multicolumn{4}{|c|}{ Host Reaction* } & \multirow{2}{*}{ Earliness } & Out Yielded & $\begin{array}{c}\text { No. of selected } \\
\text { variants }\end{array}$ \\
\cline { 2 - 5 } & R & MR & MS & S & & 31 & 38 \\
BROWN RUST & 11 & 26 & 18 & 80 & 31 & 38 & 12 \\
YELLOW RUST & 8 & 19 & 32 & 76 & 31 & 38 & 8 \\
STEM RUST & 5 & 13 & 26 & 93 & 31 & 38 & 14 \\
COMMON BUNT & 5 & 17 & - & 113 & 31 & 38 & 17 \\
LODGING & 33 & 65 & 27 & 8 & 31 & 38 & 5 \\
DROUGT TOLERANCE & 6 & 18 & 63 & 48 & 31 & \\
\hline
\end{tabular}

*: R, resistant; MR, moderately resistant; MS, moderately susceptible; S, susceptible

The results of Table 2 show that the average grain yield and yield components of the selected (R-30/Tamuz 2) hybrid variants compared to the local cultivar during three successive seasons 2004-2006 at Latifia; indicating that there is a clear superiority of $1-14 \%$ in the mean of grains yield of the selected genotypes on Tamuz 2 . The advantage was attributed mainly to improving grain filling rate by $37 \%$ in the best variant and $10 \%$ increase in plant tillering trait (number of ears per square meter).

Table 2. Grain yield and yield component performance of the selected ( $R$-30/Tamoz 2) hybrid variants comparing with the local cultivar in micro trials at Latifia and Jaderiah experimental station, Baghdad, Iraq during 2004-06

\begin{tabular}{|c|c|c|c|c|c|c|c|c|c|c|c|c|c|c|c|}
\hline \multirow{2}{*}{ Trait } & \multirow{2}{*}{ eason } & \multicolumn{13}{|c|}{ Genotype } & \multirow{2}{*}{$\begin{array}{l}\text { LSD } \\
0.05\end{array}$} \\
\hline & & am. 2 & 2 & 10 & 13 & 20 & 23 & 32 & 33 & 61 & 63 & 76 & 84 & 113 & \\
\hline \multirow{4}{*}{$\begin{array}{l}\text { PLANT } \\
\text { HEIGHT } \\
\quad(\mathrm{cm})\end{array}$} & & & & 98.9 & & & & & & & & & 98.4 & & 4.5 \\
\hline & & 6.3 & 97.2 & 95.4 & 87.6 & 95.3 & 0.7 & 92.4 & 99.3 & 94.8 & 97.9 & 101.2 & 88.5 & & N.S \\
\hline & 2006 & 92.1 & 98.2 & 95.6 & 88.2 & 103.4 & 103.5 & 90.6 & 107.4 & 91.0 & 105.6 & & 96.4 & 88.5 & 3.6 \\
\hline & Mean & 91.0 & 98.5 & 93.3 & 88.9 & 102.1 & 3.1 & 90.5 & 105 & 93.9 & 10 & & 94.4 & 90.7 & 4.1 \\
\hline \multirow{4}{*}{$\begin{array}{c}\text { NUMBER } \\
\text { OF SPIKE } \\
/ \mathrm{m}^{2}\end{array}$} & & 306.2 & 310.6 & 314.6 & 365.4 & 32 & $3 ?$ & 321.5 & 335 & 306 & 32 & 3 & 36 & 305 & 15.1 \\
\hline & 20 & 3 & 291.4 & 338 & & & & & & & & & & 312 & 19.3 \\
\hline & 2006 & 310.7 & 327.5 & 313.5 & & 311.0 & 306.5 & 30.4 & 326.0 & & & 312.7 & 315.3 & 303.6 & 17.9 \\
\hline & & 310.7 & & 322.0 & 342 & 31 & 321.6 & 334.0 & 326.1 & 313 & 34 & 18.6 & 338.8 & 307.1 & 7.4 \\
\hline \multirow{4}{*}{$\begin{array}{l}\text { GRAIN } \\
\text { WEIGHT } \\
\text { /SPIKE } \\
(\mathrm{g})\end{array}$} & & & & 2 & 2.2 & & 2.17 & 7 & 2.4 & 2 & 2.2 & 35 & & 1.87 & V.S \\
\hline & & 2 & & 2 & 2.3 & & 2.26 & 0 & 2.6 & & 2 & & & 2.10 & .18 \\
\hline & 2006 & 2 & & 12 & 2. & & 2.30 & 84 & 2.35 & & & & & 1.80 & 21 \\
\hline & Mean & 2.13 & .21 & 2.17 & 2.25 & 2.34 & 2.24 & 1.97 & 2.46 & 2.07 & 2.31 & 2.23 & 2.26 & 1.92 & 0.20 \\
\hline \multirow{4}{*}{$\begin{array}{c}\text { NUMBER } \\
\text { OF } \\
\text { GRAINS } \\
\text { /SPIKE } \\
\end{array}$} & & & & & & & 55.7 & & & & & & & & 3.5 \\
\hline & & & & 43.8 & 55 & & 56.9 & 50.3 & 54.5 & 47.8 & 53 & 58.3 & .3 & 55.4 & 3.1 \\
\hline & 2006 & 5 & .5 & 46.1 & 55.0 & 53.5 & 57.4 & 47.2 & 53.4 & 45.6 & 56.7 & 55.1 & 53.2 & 50.5 & 3.0 \\
\hline & Meal & 5 & 5.4 & 45.1 & 45.4 & 54.0 & 56.7 & 48.0 & 53.3 & 46.5 & 3.2 & 5.9 & 52.2 & 52.3 & 3.2 \\
\hline \multirow{4}{*}{$\begin{array}{c}1000 \\
\text { GRAIN } \\
\text { WEIGHT } \\
(\mathrm{g})\end{array}$} & & & .33 & 45.72 & 39.70 & 45.3 & 44.75 & 39.32 & 54.02 & 43.11 & 56.95 & 41.60 & 41.03 & 38.5 & 2.5 \\
\hline & & & & & & & 45.02 & 40. & 56. & 45 & & & & 40. & 1.9 \\
\hline & 2006 & 40.15 & 43.59 & 44.54 & 41.59 & 47.8 & 43.90 & 38.61 & 53.41 & 41.52 & 52. & 47.10 & 42.42 & 35.71 & 2.3 \\
\hline & & 38.95 & 44.53 & 45.82 & 41.54 & 46.73 & 44.42 & 39.42 & 54.61 & 43.42 & 53.55 & 43.90 & 42.02 & 38.27 & 2.2 \\
\hline \multirow{4}{*}{$\begin{array}{c}\text { GRAIN } \\
\text { YIELD/M } \\
\left(\mathrm{g} / \mathrm{m}^{2}\right)\end{array}$} & & 501.4 & 538.2 & 585.6 & 51 & 595 & 567.3 & 509.0 & 589.7 & 497.0 & 537.0 & 489.5 & 585.1 & 465.7 & 27.1 \\
\hline & 2005 & 487.5 & 514.0 & 554.3 & 523.5 & 524.0 & 535.0 & 489.5 & 518.6 & 503.2 & 609.6 & 513.6 & 554.8 & 495.3 & 35.5 \\
\hline & 2006 & 503.2 & 465.6 & 523.8 & 506.3 & 553.6 & 529.6 & 510.0 & 473.3 & 501.2 & 542.4 & 524.7 & 560.6 & 483. & 31.7 \\
\hline & Mean & 497.4 & 529.3 & 554.5 & 515.0 & 557.6 & 544.0 & 502.6 & 527.2 & 500.3 & 563.0 & 509.3 & 566.8 & 481.6 & 31.4 \\
\hline
\end{tabular}


Variance analysis of the data indicates the presence of significant differences among the genotypes in the mean of grain yield. Variant 84 out yielded all other genotypes with $566.8 \mathrm{~g} / \mathrm{m}^{2}$ and significantly surpassed most of the other variants including the local cultivar followed by variant no. 63 that produce $563.0 \mathrm{~g} / \mathrm{m}^{2}$, while the lowest grain yields were created by the local check and variant no.113 with 497.4 and $481.6 \mathrm{~g} / \mathrm{m}^{2}$, respectively. The high yield potential in genotype 84 is mainly attributed to the high number of spike per meter square (338.8), while in genotype 63 is due to the top grain weight and the number of spike per meter square (53.55 and 341.1).

Number of spike per unit area, number of grain per spike and grain weight are the principle grain yield component of wheat (Al-Eseel, 1998). Each character separately or in combination with each other can increase or decrease grain yield in wheat. Grain yield is a complex character that depends on a large number of environmental, morphological, and physiological factors (Alam et al., 2007). High significant differences in grain yield components among the genotypes indicate the role of hybridization as a breeding method to induce wide genetic variations in the second generation, which has assisted in selecting the promising genotypes in the segregated generations (Baktash, 2001).

Table 3 data represent grain yield and yield components of the selected (R-30/Tamuz 2) genotype compared to the common local cultivar during three successive seasons 2009-2011 under Bakrajo experimental station representing rain-fed cultivation system; Variance analysis of the data indicates the presence of significant differences among the tested genotypes in the mean of grain weight per each spike, the maximum value of grain weight was detected in genotype $84(1.97 \mathrm{~g})$ which was significantly surpassed all other genotypes followed by genotype $63(1.93 \mathrm{~g})$, while the lowest value of spike grains weight was recorded in genotype 10 (1.61 g). Significant differences were detected in the effect of the genotypes in thousand-grain weight; the highest value $(42.32 \mathrm{~g})$ was recorded in genotype 33, which was significantly surpassed all other genotypes except genotype 63 . Results also showed significant differences among the genotypes in the number of grains per spike; the highest value of this trait (56.8) was detected in genotype 84, which was significantly surpassed all other genotypes followed by genotype 63, while the lowest grain number of spikes were produced by genotype 23 (Table 3 ).

Number of grains per spike is one of the crucial components of yield. That's why any change in this value will directly affect the grain yield of the cultivar (Rajaram et al., 1996). Many biotic and abiotic factors can reduce the grain number per spike; also, the higher seed rate can result from low grains in the spike (Al-Maaroof et al., 2001).

Genotype 63 significantly surpassed all the tested genotypes in the number of spikes per meter square by producing 587.3 spike per meter square followed by genotype 84 , while the lowest spike number per unit area was produced by genotype 10 (434.5) (Table 3).

The number of spikes per unit area depends on the genotype and environment and strongly influenced by seed rate and plant density, high temperature enhances fast development of the plant and low tillers production (Loveras et al., 2004).

Significant differences also detected among the genotypes in the mean of grain yield. Genotype 63 out yielded over all other genotypes with $399.1 \mathrm{~g} / \mathrm{m}^{2}$ and significantly surpassed all other genotypes except genotype 84, while the lowest grain yields were produced by genotypes 83 with $326.6 \mathrm{~g} / \mathrm{m}^{2}$. The lesser grain yield production of the genotypes in 2010 compared with 2009 and 2011 is mainly due to the unfavorable environmental conditions and the severe epidemic of yellow rust in 2010 (Al-Maaroof et al., 2012). 
Table 3. Grain yield and yield component performance of the selected ( $R-30 /$ Tamoz 2$)$ hybrid variants comparing with the local cultivar in micro trials at Bakrajo experimental station, Sulaimania, Iraq during 2009-11

\begin{tabular}{|c|c|c|c|c|c|c|c|c|c|c|}
\hline \multirow{2}{*}{ Trait } & \multirow{2}{*}{ Season } & \multicolumn{8}{|c|}{ Genotypes } & \multirow{2}{*}{$\begin{array}{l}\text { LSD } \\
\mathbf{0 . 0 5}\end{array}$} \\
\hline & & Aras & 10 & 20 & 23 & 33 & 63 & 83 & 84 & \\
\hline \multirow{4}{*}{$\begin{array}{l}\text { PLANT } \\
\text { HEIGHT } \\
\quad(\mathrm{cm})\end{array}$} & 2009 & 87.3 & 85.6 & 94.2 & 90.5 & 94.2 & 86.3 & 81.4 & 87.4 & 3.5 \\
\hline & 2010 & 103.7 & 98.6 & 112.3 & 103.3 & 109.3 & 102.7 & 105.3 & 102.0 & 4.3 \\
\hline & 2011 & 83.7 & 85.3 & 89.4 & 81.5 & 85.4 & 84.7 & 85.3 & 84.7 & 3.6 \\
\hline & Mean & 91.6 & 89.9 & 98.7 & 91.8 & 96.3 & 91.2 & 90.7 & 91.4 & 3.7 \\
\hline \multirow{4}{*}{$\begin{array}{l}\text { NUMBER } \\
\text { OF SPIKE } \\
\quad / \mathrm{m}^{2}\end{array}$} & 2009 & 527.3 & 476.5 & 475.9 & 481.7 & 495.5 & 589.6 & 478.4 & 551.0 & 17.4 \\
\hline & 2010 & 516.1 & 453.4 & 473.2 & 516.5 & 526.9 & 612.8 & 486.7 & 536.1 & 15.2 \\
\hline & 2011 & 507.3 & 373.5 & 414.0 & 456.6 & 513.0 & 559.5 & 362.7 & 554.3 & 15.3 \\
\hline & Mean & 516.9 & 434.5 & 454.4 & 484.9 & 511.8 & 587.3 & 442.6 & 547.1 & 16.1 \\
\hline \multirow{4}{*}{$\begin{array}{l}\text { GRAIN } \\
\text { WEIGHT } \\
\text { /SPIKE } \\
(\mathrm{g})\end{array}$} & 2009 & 1.85 & 1.78 & 1.90 & 1.93 & 2.03 & 1.93 & 1.85 & 2.15 & 0.16 \\
\hline & 2010 & 1.73 & 1.65 & 1.86 & 1.91 & 1.93 & 2.06 & 1.71 & 2.16 & 0.15 \\
\hline & 2011 & 1.60 & 1.41 & 1.53 & 1.32 & 1.46 & 1.67 & 1.36 & 1.59 & 0.18 \\
\hline & Mean & 1.73 & 1.61 & 1.76 & 1.72 & 1.81 & 1.88 & 1.64 & 1.97 & 0.17 \\
\hline \multirow{4}{*}{$\begin{array}{c}\text { NUMBER } \\
\text { OF GRAINS } \\
\text { /SPIKE }\end{array}$} & 2009 & 51.8 & 50.6 & 54.21 & 48.6 & 50.1 & 56.8 & 50.5 & 55.7 & 2.9 \\
\hline & 2010 & 41.4 & 42.9 & 45.8 & 41.9 & 43.0 & 47.5 & 42.3 & 49.1 & 2.7 \\
\hline & 2011 & 48.7 & 46.1 & 48.5 & 43.3 & 41.4 & 54.5 & 45.1 & 58.2 & 3.1 \\
\hline & Mean & 47.3 & 46.5 & 49.5 & 44.6 & 45.0 & 52.9 & 46.0 & 54.3 & 3.0 \\
\hline \multirow{4}{*}{$\begin{array}{l}1000 \text { GRAIN } \\
\text { WEIGHT (g) }\end{array}$} & 2009 & 39.65 & 41.34 & 43.55 & 40.35 & 48.42 & 45.75 & 41.50 & 40.03 & 2.1 \\
\hline & 2010 & 38.31 & 37.10 & 38.63 & 46.31 & 46.70 & 44.80 & 39.21 & 38.56 & 1.9 \\
\hline & 2011 & 33.70 & 29.30 & 27.90 & 31.33 & 31.83 & 32.35 & 27.21 & 26.81 & 1.7 \\
\hline & Mean & 37.22 & 36.08 & 36,69 & 39.33 & 42.32 & 40.91 & 35.97 & 35.13 & 1.8 \\
\hline \multirow{4}{*}{$\begin{array}{l}\text { GRAIN } \\
\text { YIELD/M } \\
\left(\mathrm{g} / \mathrm{m}^{2}\right)\end{array}$} & 2009 & 328.3 & 344.2 & 398.1 & 352.7 & 371.5 & 385.5 & 330.3 & 360.9 & 23.5 \\
\hline & 2010 & 236.7 & 244.3 & 305.6 & 285.0 & 318.6 & 369.3 & 265.5 & 354.8 & 19.3 \\
\hline & 2011 & 418.2 & 385.6 & 418.0 & 389.3 & 426.3 & 442.5 & 384.0 & 409.3 & 25.6 \\
\hline & Mean & 327.7 & 358.0 & 373.9 & 342.3 & 372.1 & 399.1 & 326.6 & 375.0 & 23.4 \\
\hline
\end{tabular}

The high yield potential of genotype 63 is mainly attributed to the higher number of spike per meter square (587.3), while in genotype 84 was due to the higher number of grains per spike and number of spike per meter square (54.3 and 447.1, respectively).

Based on the above data and information concerning the performance of the tested genotypes and their response to the main wheat diseases under different environmental conditions, Genotype 63 was candidate to the large scale yield trail and multi-location test with the dominant local wheat cultivars in each location and nominated for registration and release under the name of "Maaroof".

Macro wheat yield trial results at Bakrajo experimental station (Table 4) shows that grain yield of Maaroof ranged from 3878.5 to $4548.7 \mathrm{~kg} \mathrm{ha}^{-1}$ as compared to $\mathrm{cv}$. Aras and Tamuz 2 in 2012 and 2013 for which grain yields ranged from 3454.2 to 3975.6 and 3696.8 to $4346.3 \mathrm{~kg} \mathrm{ha}^{-1}$, respectively. The new cultivar Maaroof out yielded both local cultivars by 12.3-14.4\% in Aras and 4.7-12.2\% in Tamuz 2 in 2012 and 2013, respectively.

The mean high yield potential of Maaroof (4213.6 kg ha-1) is mainly attributed to the high number of spike per meter square (601.2) which is significantly surpassed the mean of the same trait in Aras and Tamuz 2 by 5.3 and 14.5\%, respectively. Tamuz 2 significantly surpassed Maaroof and Aras in the mean number of grain per spike by $7.5 \%$ and 14\%, respectively, while Aras significantly surpassed Tamuz 2 in the mean number of spike per meter square by $8.7 \%$ (Table 4). 
Table 4. Grain yield and yield component performance of Maaroof as compared with the local cultivars in macro yield trials at Bakrajo, Sulaimania, Iraq during 2012-13

\begin{tabular}{c|c|ccc|c}
\hline \multirow{2}{*}{ Traits } & \multirow{2}{*}{ Season } & \multicolumn{3}{|c|}{ Cultivar } & \multirow{2}{*}{ LSD 0.05 } \\
\cline { 3 - 5 } & & Aras & Tamuz & Maaroof & \\
\hline GRAIN WEIGHT & 2012 & 1.54 & 1.88 & 1.71 & 0.14 \\
/SPIKE & 2013 & 1.63 & 2.06 & 1.83 & 0.17 \\
$(\mathrm{~g})$ & Mean & 1.59 & 1.97 & 1.77 & 0.15 \\
\hline \multirow{2}{*}{1000 GRAIN WEIGHT } & 2012 & 32.41 & 33.41 & 32.70 & 0.85 \\
$(\mathrm{~g})$ & 2013 & 33.30 & 37.35 & 33.81 & 1.31 \\
& Mean & 32.86 & 35.38 & 33.26 & 1.13 \\
\hline \multirow{2}{*}{ NUMBER } & 2012 & 50.5 & 59.1 & 54.2 & 1.82 \\
OF GRAINS /SPIKE & 2013 & 54.3 & 60.4 & 56.5 & 2.35 \\
& Mean & 52.4 & 59.75 & 55.4 & 2.10 \\
\hline \multirow{2}{*}{ NUMBER OF SPIKE } & 2012 & 557.3 & 513.4 & 589.1 & 23.15 \\
$/ \mathrm{m}^{2}$ & 2013 & 584.6 & 536.9 & 613.2 & 26.30 \\
& Mean & 571.0 & 525.2 & 601.2 & 24.63 \\
\hline \multirow{2}{*}{ GRAIN YIELD/M ${ }^{2}$} & 2012 & 3454.2 & 3696.8 & 3878.5 & 135.4 \\
$\left(\mathrm{~g} / \mathrm{m}^{2}\right)$ & 2013 & 3975.6 & 4346.3 & 4548.7 & 156.1 \\
& Mean & 3714.9 & 4021.5 & 4213.6 & 145.3 \\
\hline
\end{tabular}

Multi-location comparison of the new cultivar "Maaroof" with the predominant check cultivar for grain yield in 7 locations with different agro-ecological zones representing the main wheat production area's across Iraq is given in Table 5. Results revealed that Maaroof gave 14.3\% higher grain yield than the check cultivar Aras on the bases of 5 locations and $6.3 \%$ and on Tamuz 2 on the bases of four locations. Grain yield increase of Maaroof ranged from 1.5-42.6\% on Aras and 1.5 to $6.3 \%$ on Tamuz 2 based on the locations. No significant differences were obtained in the grain of Maaroof and Adana in four locations except in Erbil where Adana out-yielded Maaroof by 6.3\%.

Table 5. Grain yield performance of Maaroof compared with the local wheat cultivars at multi-location yield trials during 2014-2015

\begin{tabular}{c|cccc|c}
\hline \multirow{2}{*}{ Location } & \multicolumn{4}{|c|}{ Grain yield $\left(\mathbf{k g ~ h a}^{-\mathbf{1}}\right)$} & \multirow{2}{*}{ LSD 0.05 } \\
\cline { 2 - 4 } & Aras & Tamuz & Adana & Maaroof & \\
\hline SULAIMANI & 3567.4 & 3754.3 & 3883.1 & 3943.5 & 183.6 \\
DOHUK & 4025.1 & --- & 4050.0 & 4065.1 & N.S \\
ERBIL & 2891.5 & --- & 3180.6 & 2979.3 & 198.5 \\
KALAR & 3153.0 & --- & 3650.1 & 3585.2 & 203.0 \\
DIALA & --- & 4548.6 & -- & 5060.7 & 316.5 \\
WASIT & --- & 4165.5 & --- & 4465.0 & 276.4 \\
NINEVEH & 2307.4 & 3122.8 & --- & 3291.5 & 235.8 \\
MEAN & 3189.9 & 3897.8 & 3690.9 & 3912.9 & - \\
\hline
\end{tabular}

Differences in genotype performance in different locations clearly state the interaction between the genotype and environment in each location as it is indicated in earlier studies (Annicchiarico, 2002).

Table 6 results represent a wide range of host reaction between the tested bread wheat cultivars with the natural populations of $P$. striiformis, $P$. graminis f.sp tritici and P. triticina pathogens started from high resistance reaction in Maaroof to high susceptibility in SaberBeg and Adana. Maaroof explored multiple resistance reaction to yellow and stem rust diseases and moderately resistance to brown rust diseases during the 
severe Epidemics of the diseases through the study period. While all the local cultivars showed moderately susceptible to highly susceptible response to yellow and brown rust diseases, and only susceptible to highly susceptible response to stem rust disease. Furthermore, high significant differences between the tested cultivars in coefficient of infection value (C.I), the highest amount of C.I was recorded in Saber Beg and Maxipak to yellow rust (10.02 and 81.3, respectively), and brown rust disease (9.70 and 9.25) respectively, while to stem rust detected in SaberBeg and Adana (8.87 and 8.79, respectively). The new cultivar Maaroof showed the lowest C.I value to the three rust diseases. Maaroof significantly decreased the coefficient of infection value to yellow rust by $95-99 \%$, Stem rust by $97-98 \%$ and brown rust by $90-95 \%$ as compared with the commercial wheat cultivars.

Table 6. Mean coefficient of infection value (CI) and infection type (IT) of Maaroof to yellow, brown and black stem rust diseases as compared with the local wheat cultivars during the epidemic of each disease during 2010 to 2014

\begin{tabular}{|c|c|c|c|c|c|c|c|c|}
\hline \multirow{2}{*}{ Cultivar } & \multicolumn{2}{|c|}{ Yellow Rust } & \multicolumn{2}{|c|}{ Stem Rust } & \multicolumn{2}{|c|}{ Brown Rust } & \multicolumn{2}{|c|}{ Mean } \\
\hline & IT $^{1}$ & $\mathrm{CI}^{2}$ & IT & CI & IT & CI & IT & CI \\
\hline \multirow[b]{2}{*}{ SABERBEG } & \multirow[b]{2}{*}{ HS } & 100.0 & \multirow[b]{2}{*}{ HS } & 78.3 & \multirow[b]{2}{*}{ HS } & 93.5 & \multirow[b]{2}{*}{ HS } & 90.6 \\
\hline & & $10.02^{3}$ & & 8.87 & & 9.70 & & 9.54 \\
\hline \multirow{2}{*}{ ARAS } & \multirow{2}{*}{ S } & 77.5 & \multirow{2}{*}{ S } & 63.3 & \multirow{2}{*}{ S } & 56.4 & \multirow{2}{*}{ S } & 65.7 \\
\hline & & 8.83 & & 7.99 & & 7.54 & & 8.14 \\
\hline \multirow{2}{*}{ MAXIPAK } & \multirow{2}{*}{$S$} & 81.3 & \multirow{2}{*}{ S } & 76.0 & \multirow{2}{*}{$S$} & 85.0 & \multirow{2}{*}{ S } & 80.8 \\
\hline & & 9.04 & & 8.75 & & 9.25 & & 9.02 \\
\hline \multirow{2}{*}{ TAMUZ 2} & \multirow{2}{*}{ MSS } & 56.0 & \multirow{2}{*}{$\mathrm{S}$} & 53.7 & \multirow{2}{*}{$S$} & 60.3 & \multirow{2}{*}{ MSS } & 56.7 \\
\hline & & 7.52 & & 7.36 & & 7.80 & & 7.56 \\
\hline \multirow{2}{*}{ ADANA } & \multirow{2}{*}{ MS } & 30.5 & \multirow{2}{*}{ HS } & 76.7 & \multirow{2}{*}{ MSS } & 43.0 & \multirow{2}{*}{ MSHS } & 50.1 \\
\hline & & 5.57 & & 8.79 & & 6.60 & & 7.11 \\
\hline \multirow{2}{*}{ MAAROOF } & \multirow[b]{2}{*}{$\mathrm{R}$} & 0.9 & \multirow{2}{*}{$\mathrm{R}$} & 1.1 & \multirow{2}{*}{ MR } & 4.3 & \multirow{2}{*}{ RMR } & 2.7 \\
\hline & & 1.18 & & 1.26 & & 2.55 & & 1.79 \\
\hline LSD 0.05 & & 1.23 & & 0.85 & & 0.91 & & 0.99 \\
\hline
\end{tabular}

1. IT: Infection Type, $\mathrm{R}=$ Resistant, $\mathrm{MR}=$ Moderately Resistant, $\mathrm{MS}=$ Moderately Susceptible, $\mathrm{S}=$ Susceptible, HS= Highly Susceptible (Stakman et al., 1962).

2. Coefficient of infection (CI): calculated by multiplying the Disease severity (DS)value with Infection Type (IT) (Roelfs et al., 1992).

3. Data transformed using Arcsine Transformation Formula for analysis purpose

The coefficient of infection value facilitates the statistical ranking or comparison between the genotypes with different responses to the disease. It is adding two separate factors in a single value results in nearly equal coefficient but from different disease score. The differences in the genetic background of resistance reflect the differences in the infection type toward the disease. The infection type in some cultivars may be changed by time due to the appearance of new virulences in the pathogen population. Some cultivar may stay resistant to many years, but after a period it will be susceptible. Al-Maaroof et al. (1995) mentioned Tamuz 2 was resistant at the time of release in 1992 while later on became susceptible. An unknown gene identified to confer resistance to Tamuz 2 (Al-Maaroof et al., 2005). The ability of the pathogen to change itself and its virulence and appearance of more aggressive pathogen might happen by the sexual reproduction, combination or crossing methods and other mechanisms. Hence, it is essential to study the pathogen population annually to recognize the new virulence's that may come from different countries mainly the disease is airborne, which make it very difficult to control, and it may overcome resistance of some cultivars after release 
according to boom and bust cycle (Roelfs et al., 1992). Possessing more resistant genes in one cultivar increased the time of resistance stability, and decrease the probability of developing new virulence's (Messmer et al., 2000; Marasas et al., 2001). Based on this fact, we started our breeding program to improve resistance level in Tamuz 2.

Recently, many new virulence's and races were detected in Iraq that can attack most of the local wheat cultivars, such as Yr27 in P. striiformis population and race TKKTF and TTTTF in P. graminis populations (Al-Maaroof et al., 2015; Al-Maaroof, 2017).

The new promising genotype "Maaroof" was a candidate for registration and release as a new wheat cultivar for irrigated and rain-fed area's in Iraq due to its higher grain yield potential over the local commercial cultivars in the presence and absence of rust diseases. Mean coefficient infection of the cultivar was $0,1.2$, and 4.3 to yellow, stem, and brown rust diseases, respectively. It was also moderately resistant to common bunt, leaf blotch diseases, and tolerant to drought (Table 7). Molecular marker analysis of Maaroof using twelve SSR markers indicated the presence of the known resistant genes $L r 24$ and $L r 46$ to leaf rust disease, $\mathrm{Yr} 29$ to yellow rust disease and $S r 22, S r 36$ and $S r 46$ to stem rust disease. Presence of some other unknown resistant genes as well probably will participate in conferring the multiple resistance to this cultivar against the three rust diseases at the adult plant stage. Yield potential of the new cultivar "Maaroof" was 10$19 \%$ higher than Araz and Tamuz 2. Grain yield potential of Maaroof on farm-scale ranged from 3750 and $4750 \mathrm{~kg} / \mathrm{ha}$ under rain-fed and irrigated conditions, respectively. Most of the agronomic traits, qualitative and quantitative characteristics of the new bread wheat cultivar "Maaroof" presented in Table 7 which indicates that Maaroof has shown good suitability for industrial and product making as well. It possesses higher value for other quality traits like protein content (15\%), hectoliter weight (79.1), Specific loaf volume $\left(\mathrm{cm}^{3} / \mathrm{g}\right)(2.37)$ that fall in the category of good quality according to the grain quality standers (AACC, 2000). Physiochemical, rheological, and baking characteristics of Maaroof is also confirmed in earlier studies (Sabir and Al-Maaroof, 2018).

Table 7. Some agronomic traits, qualitative and quantitative characteristics of the new bread wheat cultivar "Maaroof"

\begin{tabular}{c|c|c|c|c|c}
\hline \multicolumn{2}{c|}{ Agronomic traits } & \multicolumn{2}{c}{ Grain yield \& quality } & \multicolumn{2}{c}{$\begin{array}{c}\text { Biotic \& abiotic } \\
\text { Resistance }\end{array}$} \\
\hline PLANT HEIGHT(cm) & $100-115$ & 1000 GRAIN WEIGHT $(\mathrm{g})$ & $40-43$ & BROWN RUST & MR \\
SPIKE LENGTH (cm) & $11-12$ & No. OF GRAINS/ SPIKE & $48-58$ & YELLOW RUST & R \\
AWN LENGTH (cm) & $6-7$ & No. OF SPIKE /m ${ }^{2}$ & $450-500$ & STEM RUST & R \\
SHAPE OF AIR & Fusiform & GRAIN YIELD (kg/ha) & $4500-5000$ & COMMON BUNT & MR \\
FLOWERING TIME (d) & $110-115$ & PPROTEIN \% & 15.0 & LEAF BLOTCH & MR \\
MATURITY TIME(d) & $135-145$ & WET GLUTEN \% & 42.0 & DROUGHT & T \\
FLAG LEAF AREA (cm $\left.{ }^{2}\right)$ & $40-52$ & FLOUR EXTRACTION \% & 81.0 & LODGING & R \\
GRAIN SIZE \& SHAPE & Large ovoid & HECTOLETER WEIGHT & 79.1 & SALANITY & MT \\
& & (kg/hl) & & SHUTTERING & $\mathrm{R}$ \\
STEM WIDTH $(\mathrm{mm})$ & $4-4.5$ & SPECIFIC LOAF VOLUME & 2.37 & SHUTH \\
\hline
\end{tabular}

Great emphasis was carried out by college of agricultural sciences at University of Sulaimani on multiplication and delivering high-grade seeds of "Maaroof" to the farmers as a strategy to increase wheat yield potential and decrease the risk of biotic and abiotic stress to secure food in Iraq. 


\section{Conclusions}

The long term breeding program efforts led to the development of the new promising wheat cultivar Maaroof which was registered and released by the national committee of registration and release of agricultural cultivars/Iraqi ministry of agriculture according to order no. 40 dated $30^{\text {th }}$ October, 2014 as a new cultivar with high yield potential under irrigated and rain-fed conditions coupled with multi-resistance to the three kinds of rusts and bunt diseases and has better quality traits.

The new variety may provide an excellent choice to the farmers in different agroecological zones of Iraq to increase wheat yield under low inputs and stress conditions. Furthermore, it can help in reducing the pollution risk of pesticide application in Iraq.

Acknowledgments. The first author is highly appreciable to the International Center for Agricultural Research in the Dry Areas (ICARDA) for providing seeds of the resistant sources to rust diseases, Ministry of Science and Technology (MOST) for funding the initial stage of the program, and College of Agricultural Sciences, Sulaimani University for their continuous support to the project of high grade seed production of the new promising wheat cultivar and delivering it to farmers.

\section{REFERENCES}

[1] AACC. (2000): Methods of the American Association of Cereal Chemistry. - Am. Assoc. Cereal Chem. Inc., St. Paul, Minnesota, 2000.

[2] Alam, M. Z., Haider, S. A., Paul, N. K. (2007): Yield and yield components of Barely (Hordeum vulgaris L.) cultivars in relation to nitrogen. - Fertilizer of Applied Research 3: 1022-1026.

[3] Al-Eseel, A. S. (1998): Genotypic and Phenotypic Correlations and Path Coefficients for Agronomy Characters in Bread Wheat (Triticum aestivum L.). - PhD Dissertation. Agri. Coll. Univ. of Baghdad. pp: 107.

[4] Al-Maaroof, E. M. (2017): Identification of physiological races of Puccinia graminis f. sp. tritici in Iraq. - Journal of Wheat Research 9: 47-53.

[5] Al-Maaroof, E. M., Ahmed, M. Y., Hussein, W. U. (2003): Virulence of wheat yellow rust disease in Iraq. - Iraqi J. of Biol. 13: 1-10.

[6] Al-Maaroof, E. M., Hadwan, H. A., Mohamed, L. O., Naser, A. H., Abdul Razak, A. M., Naser, H. M., Ali, S., Fattah, S., Rasheed, N., Laize, M., Naif, R., Tufeek, K. (2012): Serious outbreak of wheat stripe rust disease in Iraq. - Journal of University of Duhok 15: 358-369.

[7] Al-Maaroof, E. M., Hovmoler, M., Ali, R. M., Mohamed, H. A., Naser, A., Mohammed, L. O. (2015): Detection of Yr27 virulence in Puccinia striiformis f.sp. tritici population on wheat in Iraq. - Journal of wheat research 7: 39-47.

[8] Al-Maaroof, E. M., Ibrahim, I. F., Aboud, A. R. (2001): Effect of leaf rust disease (Puccinia recondita Rob ex Desm tritici) on different wheat cultivars and genotypes in Iraq. - Dirasat Journal for Agriculture Science 28: 111-120.

[9] Al-Maaroof, E. M., Ibrahim, I. F., Al-Janabi, A. A. (1995): Host reaction of some wheat cultivars with Puccinia recondita Rob. ex Desm. f. sp. tritici in Iraq. - Arab Journal of Plant Protection 13: 86-88.

[10] Al-Maaroof, E. M., Latif, M. M., Said, H. A., Aboud, A. R. (2002): Detecting the effective resistant genes to leaf rust disease Puccinia recondita Rob ex Desm tritici on wheat in Iraq. - Arab Journal of Plant Protection 20: 118-125.

[11] Al-Maaroof, E. M., Naser, A. H., Naser, H. M., Mohammed, L. O. (2010): New virulence of Puccinia striiformis f.sp. trittici on wheat in Iraq. - Proceedings of the Borlaug Global 
Rust initiative 2010 Technical work shop (BGRI), 30 May-4 June, 2010, St., Petersburg, Russia, 82p.

[12] Al-Maaroof, E. M., Nori, A. M. (2018): Yellow rust development on different wheat genotypes. - Journal of Zankoy Sulaimani Part-A, Special issue: 177-188.

[13] Al-Maaroof, E. M., Singh, R. P., Huerta, J., Rattu, A. (2005): Resistance of some Iraqi bread wheat cultivars to Puccinia triticina. - Phytopatholgia Mediterrania 44: 247-255.

[14] Annicchiarico, P. (2002): Genotype $x$ environment interaction-challenges and opportunities for plant breeding and cultivar recommendations. - FAO Plant Production and Protection. Paper 174, Rome.

[15] Baktash, F. Y. (2001): Improvement bread wheat by pure line selection. - Iraqi Journal of Agricultural Sciences 32(3): 87-92.

[16] Bell, M. A., Fischer, R. A. (1994): Guide to plant and crop sampling; Measurements and observations for agronomic and physiological research in small grain cereals. - Wheat special report no. 32. Mexico, D.F.: CIMMYT.

[17] Dodov, D., Todorova, V. (1974): Physiological specialization of common bunt of wheat (Tilletia leaves and T. tritici) in Bulgaria. - Academic of Science 25: 181-197.

[18] FAO. (2018): Global information and early warning system on food and agriculture. "Iraq: GIEWS Country Brief." March 2016.

[19] FAOSTAT. (2018): World food and agriculture, statistical pocket book 2018. - Food and Agriculture Organization of the United Nations, Rome 254p.

[20] Goates, B. J. (1996): Common bunt and dwarf bunt. - In: Wilcoxon, R. D., Saari, E. E. (eds.) Bunt and smut diseases of wheat: concepts and methods of disease management. CIMMYT, Mexico D.F., pp 12-25.

[21] Ibrahim, I. F., Al-Maaroof, E. M., Al-Ubaidi, M. O., Al-Janabi, K. K., Al-Janabi, A. A. (1993a): Induction of a new Iraqi wheat cultivar by gamma rays. Rachis. - Barley \& Wheat Newsletter 12: 28-35.

[22] Ibrahim, I. F., Al-Ubaidi, M. O., Al-Maaroof, E. M., Al-Janabi, A. A., Al-Janabi, K. K., Ali, A. H. (1993b): Induced new wheat cultivar by gamma irradiation. - Proceedings of the Workshop on Technology Transfer in the Production of Cereals and Legumes. Sep., 20-22, 1993, pp 47-54. Mosul, Iraq.

[23] Lewellen, R. T., Sharp, E., Hehn, E. R. (1967): Major and Minor genes in wheat for resistance of Puccinia striiformis and their response to temperature changes. - Canadian Journal of Botany 45: 2155-2172.

[24] Line, R. F., Chen, X. (1995): Success in breeding for and managing durable resistance to wheat rusts. - Plant Disease 79(12): 1254-1255.

[25] Loveras, J., Manent, J., Viudas, J., Lopez, A., Santiveri, P. (2004): Seeding rate influence on yield and yield component of irrigated winter wheat in a Mediterranean climate. Agronomy Journal 96: 1258-1265.

[26] Marasas, C. N., Smale, M., Singh, R. P., Pingali, P. (2001): The global economic impact of nonspecific leaf rust resistance in modern CIMMYT derived spring bread wheat: a preliminary report. - CIMMYT. http: www cmmyt.org/research/wheat/index htm.

[27] Messmer, M. M., Seyfarth, R., Keller, M., Schachermayr, G., Winzeler, M., Zanetti, N., Feuillet, C., Keller, B. (2000): Genetic analysis of durable leaf rust resistance in winter wheat. - Theoretical Applied Genetics 100: 419-431.

[28] NCFRRAV. (2014): Agricultural Cultivars and Hybrids Database. - National Committee for Registration and Release of Agricultural Varieties/Iraqi Ministry of Agriculture.

[29] Pessarakli, M. (2011): Handbook of plant and crop stress. - CRC Press London, 1195p.

[30] Rajaram, S., Braun, H., Van Gingle, M. (1996): CIMMYT, Approach to breed for drought tolerance. - Euphytica 92: 147-153.

[31] Roelfs, A. P., Singh, R. P., Saari, E. E. (1992): Rust disease of wheat, Concepts methods of disease management. - Mexico, D.F, CIMMYT. P81(1992). 
[32] Sabir, D. A., Al-Maaroof, E. M. (2018): Evaluation of physiochemical, rheological and baking characteristics of some wheat genotypes and cultivars. - Proceedings of the LACC4 \& IGW, 11-17 -03-2018, Mexico City, Mexico.

[33] Salman, R. M., Mahdi, A. S. (2005): Selection new promising lines of bread wheat. - The Iraqi Journal of Agricultural Sciences 36(5): 67-74.

[34] Singh, R. P., Duvillier, E., Huerta-Espino, J. (2004): Virulence to yellow rust resistance gene Yr27. - In: A new threat to stable wheat production in Asia. (Abs.). Second Regional yellow rust conference for CWANA; Islamabad, Pakistan, 22-26 March, 2004.

[35] Singh, R. P., Trethowan, R. (2007): Breeding spring bread wheat for irrigated and rain-fed production systems of the developing world. - In: Kang, M., Priyadarshan, P. M. (eds.) Breeding major food staples. Blackwell Publishing, Iowa, USA, pp 109-140.

[36] Stakman, E. C., Stewart, D. M., Loegering, W. Q. (1962): Identification of physiologic races of Puccinia graminis var. tritici. - U.S. Agriculture Research Service, E-617(rev), USA, 53p.

[37] USDA. (2015): Long-Term Projections Report. - OCE- 2015-1, 97pp. 